\title{
Olympic Medicine
}

\section{Citation}

Jones, David S. 2012. "Olympic Medicine." New England Journal of Medicine 367 (4) (July 26):

289-292. doi:10.1056/nejmp1207775. http://dx.doi.org/10.1056/NEJMp1207775.

\section{Published Version}

doi:10.1056/nejmp1207775

\section{Permanent link}

http://nrs.harvard.edu/urn-3:HUL.InstRepos:11880310

\section{Terms of Use}

This article was downloaded from Harvard University's DASH repository, and is made available under the terms and conditions applicable to Open Access Policy Articles, as set forth at http:// nrs.harvard.edu/urn-3:HUL.InstRepos:dash.current.terms-of-use\#OAP

\section{Share Your Story}

The Harvard community has made this article openly available.

Please share how this access benefits you. Submit a story.

Accessibility 
Olympic Medicine

David S. Jones, M.D., Ph.D.

In July 1912, the Boston Medical and Surgical Journal celebrated "American Supremacy" (1912; see box for historical Journal articles cited), noting that the "overwhelming success of the American athletes at the current Olympic games in Stockholm is as interesting physiologically as it is nationally gratifying." Although Sweden won the most medals, athletes from the United States won the gold medal count by the thinnest margin, 25 to 24 . What accounted for their dominance? The large population of the United States "is more mixed of all races, and we should therefore be able to select the best strains and breed the best mixtures." American athletes were "better nourished and conditioned" than their competition, "which again should conduce to racial physical superiority." To top it off, "the intensity of our national disposition leads our athletes to train much more eagerly and consistently, and with a keener professional intentness for winning." Though eugenic undertones have faded, physicians have maintained their interest in the Olympics. The strobe of the quadrennial competitions illuminates dramatic changes in medicine and sport.

Even before Pierre de Coubertin revived the Olympics in 1896, lore from the ancient games circulated in the medical literature. An 1851 essay about the power of mind over body described "the old Greek who died on the spot from excess of joy on seeing his three sons crowned with laurel at the Olympic games" (1851). Oliver Wendell Holmes invoked this same episode in his valedictory to Harvard medical graduates (1858). Other authors drew competing lessons from the Olympic legacy. One warned 
that excessive athletic training diverted energy from mental development, leaving adolescents "listless and stupid": "It was especially remarked by the Greeks that no one who in boyhood won the prize at the Olympic games ever distinguished himself afterwards" (1867). An 1891 review, in contrast, hoped that educators would learn from the ancient techniques and improve athletic training in U.S. schools (1891).

When the modern games began in Athens in 1896, physicians only slowly became interested - and mostly in marathons. Heat and humidity tormented marathoners in St. Louis in 1904: only 14 of 27 finished. The winner, who sustained himself during the race with strychnine sulfate, five eggs, and brandy, required the care of four physicians in the aftermath. Heat caused problems again in London and Stockholm. When the games resumed in Antwerp in 1920, athletes were subjected to physical examinations. The United States sent its first team physician — one who had fenced in Stockholm — to the Paris games in 1924. Medical scrutiny has continued ever since. ${ }^{1}$

Physicians have been interested in the Olympics for many reasons. In the 1920s, they probed the limits of human physiology. One group studied the Yale heavyweight rowers who won gold in Paris. An ingenious contraption revealed that at their racing speed $-12 \mathrm{mph}$ - the eight men produced four horsepower, a 20-fold increase over resting metabolism (1925). A 1937 study found that athletes at the 1936 Berlin games consumed 7300 calories each day (1937).

Sometimes the venue itself became the issue. The United States threatened to boycott the Berlin games until Hitler relented and allowed black and Jewish athletes to compete. Ignoring these tensions, the Journal, which had published a favorable review of Nazi health insurance in 1935 (1935), advertised the exhibits and lectures on "Medical 
Theory and Practice in the New Germany" that had been organized for physicians who visited the Olympics (1936). Boycott politics surfaced again when the Journal's editor, Arnold Relman, visited the Soviet Union in 1980. Relations had been strained by tensions over the Soviet invasion of Afghanistan and the United States' threat to boycott the Moscow games (1980). Other venues created medical concerns. Roger Bannister, who became a neurologist after breaking the 4-minute mile, "thoroughly disapproved" of holding the 1968 games at high altitude in Mexico City (1968). And indeed several hundred athletes collapsed at those Olympics, from migraine, shock, syncope, or emotional excitement (1969). Fears of local pathogens emerged before the Olympics in Seoul (Japanese encephalitis) and Barcelona (multidrug-resistant strep) (1988a, 1988b, 1992a). Each warning met with vehement rebuttal (1988c, 1992b). Olympic events now attract millions of visitors and require careful medical and public health planning. ${ }^{2}$ Fear of terrorism emerged as well, especially after the Atlanta bombing, which left 2 people dead and 111 injured (2006).

The safety of Olympic sports has remained an enduring concern. The French Academy of Medicine appointed a committee before the 1924 Paris games "to study the effects of modern athletics on the human system" (1924). The resulting tests "revealed an alarming number of cases of athletic heart." Subsequent studies from the 1920s (on athletes from the 1928 Amsterdam games) through the 1990s (on 310 Italian Olympians) have produced conflicting evidence on the question of whether intense physical training can cause cardiac hypertrophy $(1930,1991 a)$. Some sports received special scrutiny. On the eve of the Atlanta games, a scathing review likened women's gymnastics to child abuse (1996), arguing that although "elite gymnastics can provide a profoundly 
meaningful experience for the athletes," it could also "result in serious, life-endangering physical and psychological disabilities.” Citing injuries, eating disorders, and social problems, the authors warned that "talented youngsters at every competitive level should be supported rather than crippled by their sport as they enter adulthood."

A different kind of medical scrutiny emerged in the 1950s. Commenting on a symposium about "Pheidippidian physiology," a 1957 editorial highlighted the recent dramatic improvements in performance at track-and-field events (1957). What explained "these epidemics of broken records"? The editorial considered possible contributions from training, diet, antibiotics, and motivation, but focused on "a speculative explanation": "that amphetamine is being used by some athletes to help them break otherwise unassailable records." Such practices, if they were in fact occurring, were both dangerous and "ethically undesirable." Each passing decade brought new scandals about performance-enhancing drugs. After the U.S. Olympic Committee admitted that seven cyclists (including four medalists) had received blood transfusions at the Los Angeles games, a Sounding Board article condemned this practice (1985). Not only was this practice dangerous, especially in light of the emerging AIDS epidemic; it also "represents an attempt to use a medical therapy to provide athletes with an unfair competitive advantage." When Ben Johnson was stripped of his gold medal at the Seoul Olympics, the Journal reviewed the medical risks and legal consequences of anabolic steroids (1989). Erythropoietin came next. As a Dutch physiologist wrote in the Journal in 1991, "the next Olympic Games have already been nicknamed the "Hematocrit Olympics"” (1991b). Physicians' obligation seemed clear: “the medical profession has a responsibility to consider carefully these untoward consequences of scientific progress." 
Performance-enhancing drugs have cast a long shadow on the modern Olympics.

Whether the agents are strychnine, heroin, cocaine, or morphine that athletes used in

Athens in 1896, or the amphetamines, steroids, and erythropoietin that some use today,

the dilemma remains the same. As a sports medicine specialist noted in 2004, the

"attraction of performance-enhancing drugs is simply that they permit the fulfillment of

the mythical promise of boundless athletic performance — the hubristic 'faster, higher, stronger' motto of the Olympic Games" (2004). The ensuing systems of medical

surveillance have led, inevitably, to "a new type of competition," in which some athletes try to stay one step ahead of the authorities (2001).

The arms race will continue as medical science produces ever newer means of performance enhancement. Will future athletes try growth factors or gene therapy ${ }^{3}$ One thing is certain: the Olympics will remain an object of medical fascination.

From the Department of Global Health and Social Medicine, Harvard Medical School, Boston; and the Department of the History of Science, Harvard University, Cambridge, MA.

Disclosure forms provided by the author are available with the full text of this article at NEJM.org.

\section{References}

1. Ryan AJ. A medical history of the Olympic games. JAMA 1968;205;715-20.

2 Green GB, Burnham G. Health care at mass gatherings. JAMA 1998;279;1485-6. 
3. Sandel MJ. The case against perfection: ethics in the age of genetic engineering.

Cambridge: Harvard University Press, 2007.

[box]

\section{Historical Journal Articles Cited.}

\section{Boston Medical and Surgical Journal}

1851. Badeley JC. On the reciprocal agencies of mind and matter. 45:195-201.

1858. Holmes OW. Valedictory address. 53:149-59.

1867. The abuse of physical exercise. $77: 425$.

1891. Hartwell EM. The principal types of physical training compared. 125:641-4.

1912. American supremacy at the Olympic games. 167:102.

1924. French Academy of Medicine names committee to study effects on the human system of modern athletics. 190:397.

1925. Stiles PG. Recent progress in physiology. 193:873-6.

\section{New England Journal of Medicine}

1930. Bland EF, Sprague HB. Progress in the study of cardiovascular disease in 1929.

203:574-91

1935. Davis MM, Kroeger G. Recent changes in German health insurance under the Hitler government. 212:1037-42.

1936. Information for doctors during the Olympiad in Berlin. 215:211. 
1937. Burnett FL. Nutrition, health and disease. 217:515-27.

1957. Icarus complex. 257:1194-5.

1968. Lister J. After-dinner speaking — "Hello, there!" 278:953-4.

1969. Jokl E. Altitude diseases. 280:1420-1.

1980. Relman AS. Moscow in January. 302:532-4.

1985. Klein HG. Blood transfusion and athletics: games people play. 312:854-6.

1988a. Marcus LC. Liability for vaccine-related injuries. 318:191.

1988b. McKinney WP, Barnas GP. Japanese encephalitis vaccine: an orphan product in need of adoption. 318:255-6.

1988c. Steffer R. Japanese encephalitis vaccine: necessary for the Olympics in Seoul? 319:251.

1989. Hallagan JB, Hallagan LF, Snyder MB. Anabolic-androgenic steroid use by athletes. 321:1042-5.

1991a. Pelliccia A, Maron BJ, Spataro A, Proschan MA, Spirito P. The upper limit of physiologic cardiac hypertrophy in highly trained elite athletes. 324:295-301.

1991b. Romijn JA. Erythropoietin. 325: 1176-7.

1992a. Barnett ED, Klein JO, Teele DW. Pneumococcal vaccine for Olympic athletes and visitors to Spain. $326: 1572$.

1992b. Plasencia A, Segura A, Farrés J, Cuervo JI. Pneumococcal vaccine for Olympic athletes and visitors to Spain. 327:437.

1996. Tofler IR, Stryer BK, Micheli LJ, Herman LR. Physical and emotional problems of elite female gymnasts. 335:281-3.

2001. Zarins B. Book review — endurance in sport. 344:1025-6. 
2004. Noakes TD. Tainted glory — doping and athletic performance. 351:847-9.

2006. Kellerman AL. Crisis in the emergency department. 355:1300-3. 
